\title{
Everyday Children Feeding Practices in a Modern Russian Family
}

\author{
Ramil M. Sadykov and Iuliia V. Migunova* \\ Institute for Social and Economic Research \\ Ufa Scientific Centre of the RAS \\ 71 Oktyabrya, Ufa, 450054, Russia
}

Received 01.05.2017, received in revised form 03.10.2017, accepted 10.10.2017

The article deals with the problem of the product intake limitation in families with children. The work emphasizes that the population nutrition problem has important social significance and refers to the global categories that play an important role in ensuring the quality and length of human life and health. Therefore, the given problem is studied not only in the scope of medical science, but also can be presented in the social and economic aspect. Practice shows that the state of child nutrition in families with a low income does not match the medical and biological standards ratified in the modern society. A common family often gets into a category of such households, where with the birth of children, especially if there are several children, the family life level rapidly decreases. The article provides the analysis of alimentary and energy value of nutrition in all the observed family types. It is emphasized that the nutritive value of food-stuff in households with one or two children is much higher than in large ones. Food ration within its nutrients in families with children does not correspond to the living wage. There is a strong tendency of increasing a part of budget expenses of big families on food and reducing the health maintenance and educational expenses. Moreover, an increase in the amount of children redoubles the tendency. Thus, nutrition quality is higher in families with one child than in large households.

Keywords: child nutrition, healthy eating, social nutrition, energy and nutritional value of food, food quality, "poor" type of food, poverty, family with children.

This study was performed as part of the state task of ISEI RAS on the subject № 0253-2014-0001 "Strategic management of key potentials of different levels of socio-economic systems from the standpoint of national security" (state registration № 01201456661).

DOI: 10.17516/1997-1370-0156.

Research area: social structure, social institutions and processes.

The development of human health science disposes objective data about the role of nutrition in development and support of adequate demands of human vitality and their social activity and decent quality of life in society. The population nutrition state is related to the main indicators of the reached level of social and economic development of a country, demonstrates the wealth of citizens and determines the population health, its social potential. According to the above

(C) Siberian Federal University. All rights reserved

* Corresponding author E-mail address: sadikovrm@mail.ru 
stated arguments, the study of the child nutrition state sheds light onto the problem of human capital formation of a country, thus solving social and economic objectives in various degrees in the future (Moiseeva, 2012).

In the modern science the problem of children's feeding is closely connected with sociology of medicine, because there are investigated medical and biologic factors of a diet of a child. Thus, the problem of nutrition has become the object of interdisciplinary scientific knowledge: medicine, ethnographies, sociology, economy, etc. It should be noted that basically the specified problematics reveals itself in a context of three approaches: natural-science, historical and ethnographic, sociological. Based on the naturalscience approach, the studies are characterized by interrelation of food allowance of people and their physical state of health. Development of techniques and recommendations for the proper and healthy diet for the purpose of care for the health status of the population and a close relation with medicine are an important feature of this approach (A.A. Baranov, V.A. Tutelian, A.K. Baturin and others) (Baranov et al., 2009; Tutelian et al., 2014). Within the historical and ethnographical approach the problem of nutrition is being investigated as a socio-cultural phenomenon, a kind of an ethnic tradition, the main element of the material culture of people (S.A. Arutiunov, S.A. Tokarev and others) (Arutiunov, 2011; Tokarev, Polovodova, 2010).

Supporters of the sociological approach analyze the role and value of nutrition in the organization of human social life. The methodological base of this approach was a theoretical tradition created by P. Bourdieu that linked a lifestyle and consumption of human with the social structure of society. Consequently, according to the food preferences of an individual we can determine his belonging to a certain social stratum (P.A. Sorokin, Y.V. Veselov,
S.A. Kravchenko and others) (Kravchenko, 2015; Veselov, 2015). A modern foreign researcher of the nutritional issues J. Coveney emphasizes that food still remains an identifier and marker of class, culture and civilization (Coveney, 2014).

The problem of rational and healthy nutrition of the population has a pronounced social meaning. Nourishment plays an important social role in ensuring the quality and length of human life and health. In this connection the nutrition state problem is not only medical, but also social. The research of the discussed problem has shown that the nutrition problem in Russia deals with two difficulties. Firstly, the limit of food - stuff consumption by poor families with children, especially large families (Albitskii et al., 2007). Secondly, the imbalance of metabolic processes of the population due to the basic food ingredients (proteins, fats, carbohydrates), vitamins, minerals (Deev et al., 2002). This situation is primarily connected with the inability to eat properly, the lack of knowledge about the nourishment role in shaping and maintaining health and vitality.

At the heart of these processes there lies children and adolescents health condition. In other words, high-quality and healthy eating in childhood contributes to harmonious and full physical and mental development, high productivity and educational achievements of a student, creating conditions for the adaptation to the surrounding society, affecting the quality of life and is also an important factor of forming and maintaining the health of the rising generation (Nauchnye osnovy, 2010; Migunova, 2015).

The purpose of the study is to examine daily practices of child nutrition in a modern Russian family.

Material and methods. The article carries out a comparative analysis of the main characteristics of nutrition in families with children. Statistical data characterizing a 
nutritive value of food in families with children have been explored.

Results and discussion. Nowadays a tendency of deterioration of the child population health condition for all age groups in Russia has been formed, which certainly affects the quality of the human potential: health, professional skills, qualification, general culture (Kontseptual'nye, 2003). Practice shows that child nutrition in families with low incomes does not match medical and biological standards ratified in the modern society. A common family with a new-born child often gets into the category of such households, i.e. with the advent of a child, especially if there are several children, the family life level rapidly deteriorates (Migunova, 2014). That is why, in most cases, families with three or more underage children are among the poor. Thus, the population with low incomes or with their slight growth creates the background for aggravation of the problem of poverty, especially in large families (Ovcharova, Popova, 2005). In turn, a problem of the child nutrition state becomes relevant not only in low-income families, but in an average family with only one child.

It is obvious, that the high-quality variety of food is a necessary condition of both physical and mental development of a child. Food with a high biological value, including meat, fish, eggs, dairy products, vegetables, fruits, etc. should be included in the daily diet of not only children, but adults as well. The lack of the above mentioned products that are the main source of proteins and vitamins, downgrades life potential and immunity in the basic diet and can cause serious diseases and shorten lifetime. According to the statistics, poor nutrition is a direct consequence of the health drawdown of the growing generation (Pitanie i zdorov'e, 2002; Tutelian et al., 2010). For example, there has been a steady increase in the number of children in the class of digestive diseases: in
2011, 1794 people at the age of 14 and younger suffered from this type of a disease, in 2012, there were 1854.9 people, in 2013 - the number grew to 1880.7 people.

In turn, with the increase in the number of children in a family the value of food declines. Statistic data of 2013 show that if the withinnamed index in the households with one child was equal to $2352 \mathrm{kcal}$ per day, a significant decrease of the energy value of food in families with two, three or more children can reach 2123 and $2084 \mathrm{kcal}$ per day, accordingly. The energy value of food in families with four children and more is significantly reduced - down to $2015 \mathrm{kcal}$ per day.

Thus, a shortage of useful energy value for each member is fixed in a modern Russian family raising more than one child. Significant changes in the structure of food are noted in families with two children and more.

Raising the food quality problem, the researchers have faced the necessity of a comparative analysis of the main food characteristics in families with children (Sem'ia v Rossii, 2009). Significant changes in the structure of food are observed in families with two or more children. For example, according to the Rosstat (Federal Service of State Statistics) data for 2013, families with two children consumed $80 \mathrm{~kg}$ of grain products, families with three children had $84 \mathrm{~kg}$, families with four children and more ate $92 \mathrm{~kg}$. In its turn, a family with one child consumed $77 \mathrm{~kg}$ of meat per year, a family with two children had $67 \mathrm{~kg}$, a family with three children ate $60 \mathrm{~kg}$, a family with four children and more consumed only $45 \mathrm{~kg}$. The same should be noted while examining fish and fish products (a family with one child consumed $19 \mathrm{~kg}$ of fish per year, a family with two or three children had $16 \mathrm{~kg}$, a family with four children and more had $13 \mathrm{~kg}$ of fish per year) (Sotsial'noe polozhenie, 2014) (Table 1). 
Table 1. Consumption of food stuffs in households with children under 16 in 2013 (an average per one family member, $\mathrm{kg}$ )

\begin{tabular}{|l|c|c|c|c|}
\hline \multirow{2}{*}{\multicolumn{2}{c|}{ Food }} & \multicolumn{3}{c|}{ Households with children under the age of 16 } \\
\cline { 2 - 5 } & $\mathbf{1}$ child & $\mathbf{2}$ children & 3 children & $\begin{array}{c}\text { 4 children } \\
\text { and more }\end{array}$ \\
\hline Bread and bakery products & 86 & 80 & 84 & 92 \\
\hline Potatoes & 55 & 50 & 48 & 58 \\
\hline Vegetables and melons & 85 & 74 & 66 & 54 \\
\hline Fruits and berries & 72 & 64 & 61 & 44 \\
\hline Meat and meat products & 77 & 67 & 60 & 45 \\
\hline Milk and dairy products & 242 & 213 & 208 & 165 \\
\hline Eggs, pcs. & 192 & 168 & 163 & 136 \\
\hline Fish and fish products & 19 & 16 & 16 & 13 \\
\hline Sugar and confectionary & 28 & 26 & 26 & 26 \\
\hline Vegetable oil and other fats & 9 & 8 & 8 & 9 \\
\hline
\end{tabular}

The data presented in the table show the increase of bakery products and potato consumption in all the families with children. Reduced consumption of more useful products in terms of alimentary and energy value of food vegetables, fruits, meat, dairy and fish products, and eggs, characterizes all the studied households raising more than one child. As the data show, an extremely low level of food consumption in families with children is traced.

Therefore, inclusion of such food stuffs as meat, fish and milk in the diet of families with two or more children is replaced by less healthy, but more high-calorie and low-cost ones, which indicates the inadequate nature of nutrition of underage children in families. This "poor" type of feeding leads to an increase in protein-calorie malnutrition characterized by weight loss and low growth index of children and adolescents. Moreover, such food stuffs as fish and sea products, the level of which is particularly low in families with children, is among the required ones in the children's diet (Sadykov, Migunova, 2016).

Examining the statistical data for 2013 relating to the nutritional value in families with children, it is noted that the amount of proteins, fats and carbohydrates in households with one or two children is much higher than in large families. Besides, nowadays it is typical for the ration in small families to have a high fat content, which becomes an important factor for the rising generation's obesity. The protein content in the ration of families with one or two children corresponds to the recommended standard (about $12 \%$ ). Almost the same protein content is noted in families with two or three children $-11.7 \%$. Meanwhile, fat content in the nutrition of such families slightly exceeds the recommended norm and makes $33.2 \%$. As for the food ration in families with four children and more, the reduced protein consumption, including protein of animal origin, is recorded $10.3 \%$. This, in turn, leads to an increase in protein-calorie malnutrition in the diet of large families.

Thus, the quality of food in families with one child is higher than in households with two or more children. According to the nutritive substance, the food ration in large families does not correspond to the living wage standards (Tutelian, 2009) (Table 2). 
Table 2. The value of food in households with children aged under 16 in 2013 (average per one family member a day)

\begin{tabular}{|c|c|c|c|c|}
\hline \multirow[b]{2}{*}{ Nutritional value of food } & \multicolumn{4}{|c|}{ Households with children under the age of 16} \\
\hline & 1 child & 2 children & 3 children & $\begin{array}{l}4 \text { children } \\
\text { and more }\end{array}$ \\
\hline $\begin{array}{l}\text { Proteins, } g \\
\text { including foods of animal origin }\end{array}$ & $\begin{array}{c}70 \\
(12 \% \\
\text { calorie content) } \\
44\end{array}$ & $\begin{array}{c}63 \\
(11.8 \% \text { calorie } \\
\text { content) } \\
39\end{array}$ & $\begin{array}{c}61 \\
(11.7 \% \text { calorie } \\
\text { content) } \\
37\end{array}$ & $\begin{array}{c}53 \\
(10 \% \text { calorie } \\
\text { content }) \\
27\end{array}$ \\
\hline $\begin{array}{l}\text { Fat, } g \\
\text { including } \\
\text { foods of animal origin }\end{array}$ & $\begin{array}{c}95 \\
\text { (36.3\% calorie } \\
\text { content) } \\
60\end{array}$ & $\begin{array}{c}83 \\
\text { (35.1\% calorie } \\
\text { content) } \\
52\end{array}$ & $\begin{array}{c}77 \\
\text { (33.2\% calorie } \\
\text { content) } \\
47\end{array}$ & $\begin{array}{c}69 \\
(30 \% \text { calorie } \\
\text { content }) \\
38\end{array}$ \\
\hline $\begin{array}{l}\text { Carbohydrates, g including } \\
\text { foods of animal origin }\end{array}$ & $\begin{array}{l}30 \\
15\end{array}$ & $\begin{array}{c}278 \\
14\end{array}$ & $\begin{array}{c}283 \\
14\end{array}$ & $\begin{array}{c}292 \\
10\end{array}$ \\
\hline
\end{tabular}

Analyzing the data, characterizing the energy value of food in families with children for the period from 2010 till 2013, the authors made the following conclusion. During this period a slight energy value of food is noted in families with one child (by 2013 the figure had increased by $1.6 \%$, if compared with 2010). Meanwhile, a gradual decrease of the energy value of food is registered in households with 2 or more children. For example, by 2013 it had been reduced by 4.2 $\%$ in families, bringing up 3 children, if compared with 2010. A gradual decrease of the given figure is noted in households with 4 children or more, however, by 2013 an unexpected increase by more than $5 \%$, in comparison with the previous year, had been recorded. However, despite this fact, we cannot talk about a high-quality and adequate diet in large families (Table 3).

An important source of food in a modern family, especially in rural areas, is private farming. If we compare the share of natural products of private production, it will be much higher in large families than in families raising one or two children. It is obvious that private households are the source of the most valuable food-stuff, i.e. they provide rural population with meat, milk, potatoes, etc. Consequently, the sector of private farming is the main source of consumed food and additional incomes for the villagers (Sadykov, 2015).

However, even taking into account all sources of income, food in the household with several children still remains insufficiently complete and balanced. As a rule, in general, there is a significant lack of protein and carbohydrates, as well as the increased consumption of bread and potatoes in large families. Thus, a decrease in the energy value of food in families with several children is estimated negatively, as this fact points to the lack of nutrition in these households. Characterizing the nourishment structure in large families, a proceeding decline of more valuable and healthy food should be noted. In fact, we can state a high-quality and adequate nutrition only in families with one child (Migunova, Sadykov, 2016).

It is known that the higher the population life quality, the lower the share of expenses on food, and vice versa. According to the official data, the share of expenditure on food in large families for 2013 was $36 \%$ for families raising three children, as for the households raising four children and more, it was 38-40\% of family budget. Therefore, more than one-third of income is spent on food in large families, which states low material wealth of such families. In 
Table 3. Energy value of food in households with children aged under 16 in 2010-2013 (average per one family member, kcal)

\begin{tabular}{|c|c|c|c|c|}
\hline $\begin{array}{c}\text { Households } \\
\text { with children aged under 16 }\end{array}$ & $\mathbf{2 0 1 0}$ & $\mathbf{2 0 1 1}$ & $\mathbf{2 0 1 2}$ & $\mathbf{2 0 1 3}$ \\
\hline 1 child & 2314 & 2320 & 2332 & 2352 \\
\hline 2 children & 2152 & 2147 & 2131 & 2123 \\
\hline 3 children & 2176 & 1202 & 2088 & 2084 \\
\hline 4 children & 1966 & 1947 & 1913 & 2015 \\
\hline
\end{tabular}

this case, it is appropriate to talk about social stratification of the population of Russia on the type of food, i.e. despite the significant increase in expenses on food in such families, there is reduced consumption of the healthy, highquality food (Gaifullin et al., 2016; Sadykov, Migunova, 2016). Therefore, the lower the quality of people's life, the less they spend on maintaining health of their children, as well as their education (Sukharev, Mikhailova, 2004). According to Rosstat for the third quarter of 2014, health care expenditure in families with one child under 16 was 361.1 roubles per month, in families with two children it made 313.5 roubles per month, in families with three children it was 196.3 roubles per month and in families with four children it was 132.3 roubles per month. Thus, a clear tendency of increasing the share of budget expenditure on food in large families and reducing the expenses on health maintenance and educational needs is obvious. Moreover, the increase in the number of children in a family worsens the tendency. It is noted that with the increase in the number of children in a family, the quality of nutrition for its members noticeably worsens.

\section{References}

Albitskii, V.Y., Volgina, S.Y., Kurmaeva, E.A. (2007). Sostoianie zdorov'ia i obraz zhizni detei iz bednykh semei [Health status and lifestyles of children from poor families]. In Voprosy sovremennoi pediatrii [Current Pediatrics], 6, 25-27.

Arutiunov, S.A. (2011). Karta kul'tury pitaniia narodov mira [World food culture]. In Etnograficheskoe obozrenie [Ethnographic Review], 1, 7-16.

Baranov, A.A., Kuchma, V.R., Sukhareva, L.M. (2009). Sostoianie zdorov’ia sovremennykh detei i podrostkov i rol' mediko-sotsial'nykh faktorov $\mathrm{v}$ ego formirovanii [The state of health of today's children and adolescents and the role of medical and social factors in its formation]. In Vestnik Rossiiskoi akademii meditsinskikh nauk [Bulletin of the Russian Academy of Medical Sciences], 5, 6-10.

Coveney, J. (2014). Food. London and New York: Routledge.

Deev, A.D., Baturin, A.K., Starovoitov, M.P., Martinchik, A.N., Zemlianskaia, T.A., Shalnova, S.A., Keshabiants, E.E., Safronov, A.M. (2002). Pitanie v bednykh sem'iakh: vzrosloe trudosposobnoe naselenie [Food in poor families: adult working-age population]. In Voprosy pitaniia [Issues of nutrition], 2, 3-7.

Gaifullin, A.Y., Migunova, Iu.V., Sadykov, R.M. (2016). Differentsiatsiia pitaniia detei v sovremennykh rossiiskikh sem'iakh: sotsial'no-ekonomicheskii aspekt [Differentiation of the nutritional status of children in contemporary Russian families: a socio-economic aspect]. In Zhurnal 
nauchnykh statei "Zdorov'e i obrazovanie v XXI veke" [Journal of scientific articles "Health and Education in the 21 st century"], 2, 769-773.

Kontseptual'nye vzgliady na zdorov'e rebenka [Conceptual views on the child's health] (2003). Ed. V.N. Shestakova. Smolensk. 592 p.

Kravchenko, S.A. (2015). Sotsial'naia i kul'turnaia dinamika edy: priobreteniia i uiazvimosti [Social and cultural dynamics of food: acquisition and vulnerability]. In Sotsiologicheskie issledovaniia [Sociological studies], 1, 85-94.

Migunova, Iu.V. (2015). Poniatie zdorov'ia. Pokazateli otsenki sostoianiia zdorov'ia naselenia [The concept of health. Indicators to measure the state of health of the population]. In Izvestiia Ufimskogo nauchnogo tsentra RAN [Proceedings of the Ufa Scientific Centre of the Russian Academy of Sciences], 1, 99-105.

Migunova, Iu.V., Moiseeva, T.P. (2014). Dvukhaspektnyi kharakter problemy pitaniia detei kak faktor sotsial'noi ustoichivosti [Two-pronged nature of the problem of child nutrition as a factor of social stability]. In Sovremennye problemy nauki i obrazovaniia [Modern problems of science and education], 6. Available at: http://www.science-education.ru/120-16805 (date accessed 04/04/2016).

Migunova, Iu.V., Sadykov, R.M. (2016). Kachestvo pitaniia semei s det'mi v usloviiakh sovremennoi rossiiskoi deistvitel'nosti [The quality of food for families with children in the modern Russian reality]. In Zhurnal nauchnykh statei "Zdorov'e i obrazovanie v XXI veke" [Journal of scientific articles "Health and Education in the $21^{\text {st }}$ century"], 2, 778-782.

Moiseeva, T.P. (2012). Detskaia beznadzornost' v krupnom gorode kak faktor sderzhivaiushchii pozitivnuiu dinamiku transformatsii rossiiskogo obshchestva [Child neglect in a big city as a deterrent to the positive dynamics of transformation of Russian society]. In Vestnik VEGU [Bulletin of VEGU], 2, 40-44.

Nauchnye osnovy zdorovogo pitaniia [Scientific basis for the healthy nutrition] (2010). Moscow, Panorama. $816 \mathrm{p}$.

Ovcharova, L.N., Popova, D.O. (2005). Detskaia bednost'v Rossii. Trevozhnye tendentsii i vybor strategicheskikh deistvii-IUNISEF [Child poverty in Russia. Alarming tendencies and the selection of strategic actions - UNICEF]. Moscow, $24 \mathrm{p}$.

Pitanie i zdorov'e $v$ bednykh sem'iakh [Nutrition and health in poor families] (2002). Moscow, Prosveshhenie.

Sadykov, R.M. (2015). Rol' lichnykh podsobnykh hoziaistv v formirovanii prodovol'stvennogo rynka regiona [The role of private farms in the formation of the food market in the region]. In APK: ekonomika, upravlenie [AIC: economy, management], 6, 53-60.

Sadykov, R.M., Migunova, Iu.V. (2016a). Sotsial'nye ugrozy nepolnotsennogo pitaniia detei v sem'e [Social threats of defective child nutrition in a family]. In Sotsial'nye aspekty zdorov'ia naseleniia [Social aspects of public health], 3, 402-409.

Sadykov, R.M., Migunova, Iu.V. (2016b). Uroven' zhizni rossiiskoi sem'i i kachestvo pitaniia detei [The Russian family life standard and the quality of child's nutrition]. In Obshchestvennye nauki [Social science], 3, 545-553.

Sem'ia v Rossii: osobennosti sovremennoi zhizni i vzgliad v budushchee [Family in Russia: peculiarities of modern life and look into the future] (2009). Ed. L.N. Ovcharova, L.M. Prokofieva. Moscow. 274 p. 
Sukharev, A.G., Mikhailova, S.A. (2004). Sostoianie zdorov'ia detskogo naseleniia v napriazhennykh ekologicheskikh i sotsial'nykh usloviiakh [A health state of the child population in stressful environmental and social conditions]. In Gigiena $i$ sanitariia [Hygiene and sanitation], 1, 47-50.

Sotsial'noe polozhenie i uroven' zhizni naseleniia Rossii. Statisticheskii sbornik [The social position and standards of living of the Russian population. Statistical collection] (2014). Rosstat. Moscow.

Tokarev, S.A., Polovodova, N.S. (2010). Faktory riska i sostoianie zdorov'ia detei na Krainem Severe [Risk factors and health status of children in the Far North]. In Shkola zdorov'ia [Health School], 1, 37-41.

Tutelian, V.A., Baturin, A.K., Kon', I.J., Martinchik, A.N., Uglitskikh, A.K., Korosteleva, M.M., Toboleva, M.A., Aleshina, I.V. (2014). Rasprostranennost' ozhireniia i izbytochnoi massy tela sredi detskogo naseleniia RF: mul'titsentrovoe issledovanie [The prevalence of obesity and overweight among children population of the Russian Federation: a multicenter study]. In Pediatriia. Zhurnal im. G.N. Speranskogo [Pediatrics. Journal named after G.N. Speranskii], 5, 28-31.

Tutelian, V.A., Baturin, A.K., Kon', I.J., Safronova, A.M., Keshabiants, E.E., Starovoitov, M.L., Gmoshinskaia, M.V. (2010). Otsenka sostoianiia pitaniia i pishchevogo statusa detei grudnogo i rannego vozrasta $v$ Rossiiskoi Federatsii [Assessment of nutrition and nutritional status of infants and young children in the Russian Federation]. In Voprosy pitaniia [Issues of nutrition], 6, 57-63.

Tutelian, V.A. (2009). O normakh fiziologicheskikh potrebnostei v energii i pishchevykh veshchestvakh dlia razlichnykh grupp naseleniia Rossiiskoi Federatsii [Norms of physiological requirements in energy and nutrients in various groups of population in Russian Federation]. In Voprosy pitaniia [Issues of nutrition], 1, 4-16.

Veselov, Y.V. (2015). Povsednevnye praktiki pitaniia [Daily feeding practices]. In Sotsiologicheskie issledovaniia [Sociological studies], 1, 95-104.

\title{
Повседневные практики питания детей
}

в современной российской семье

\author{
Р.М. Садыков, Ю.В. Мигунова \\ Институт социально-экономических исследований \\ Уфимский научный центр РАН \\ Россия, 450054, Уфа, пр. Октября, 71
}

\begin{abstract}
В представленной статье рассматриваются вопросы, касаюшчеся ограниченности потребления продуктов питания семей с детьми. В работе подчеркивается, что проблема рационального питания населения имеет выраженное сочиальное значение и относится к категориям глобальных, играющих существенную роль в обеспечении качества и продолжчтельности жизни человека, его здоровья. Поэтому данная проблема исследуется не только в рамках медицинской науки, но и может быть представлена в сочиильно-экономическом аспекте. Практика показывает, что состояние питания детей в семьях с низкими доходами не соответствует утвержденным для современного общества медико-биологическим нормам.
\end{abstract}


Зачастую в разряд таких домохозяйств попадает среднестатистическая семья, где рождается ребенок, то есть с появлением детей, особенно нескольких, уровень жизни домохозяйства стремительно ухудшается. В работе представлен анализ пищевой и энергетической ценности питания во всех типах обследуемых семей. Подчёркивается, что в домохозяйствах с однимдвум детьми пищевая ценность продуктов питания значительно выме, чем в многодетных. В семьях с детьми рачион питания не соответствует нормативам прожиточного минимума по своим пищевым веществам. Прослеживается четкая тенденция повышения доли расходов бюджета многодетных семей на продукты питания и сокращение расходов на поддержание здоровья, образовательные нужды. Причем увеличение количества детей в семье усугубляет эту тенденцию. Соответственно, качество питания выще в семьях с одним ребенком, чем в домохозяйствах с двумя и более детьми.

Ключевые слова: питание детей, здоровое питание, соичильное питание, энергетическая и пищевая ценность продуктов питания, качество питания, «бедный» тип питания, бедность, семья с детьми.

Данное исследование выполнено в рамках госзадания ИСЭИ УНЦ РАН по теме № 0253-2014-0001 «Стратегическое управление ключевыми потенциалами развития разноуровневых социальноэкономических систем с позииий обеспечения национальной безопасности» (№ гос. регистращии 01201456661).

Научная специальность: 22.00.04 - социальная структура, социальные институты и процессы. 